\title{
Promoting resiliency, peer mediation and citizenship in schools: The outcomes of a three-fold research intervention
}

\author{
Angeliki Lithoxoidou* \\ Department of Primary Education, University of Western Macedonia, Florina, Greece \\ https://orcid.org/0000-0002-6814-8680 \\ Evangelia Seira \\ Department of Primary Education, University of Western Macedonia, Florina, Greece \\ https://orcid.org/0000-0001-6421-9827
}

\author{
Agapi Vrantsi \\ Department of Primary Education, University of Western Macedonia, Florina, Greece \\ https://orcid.org/0000-0002-9594-6784
}

\section{Catherine Dimitriadou}

Department of Primary Education, University of Western Macedonia, Florina, Greece https://orcid.org/0000-0002-8450-9562

Article history

Received:

23.06.2020

Received in revised form: 18.11.2020

Accepted:

03.12.2020

Key words:

Resilience;

peer mediation; citizenship education;

Critical Pedagogy
Given the current unstable worldwide conditions, school is considered an essential component for the empowerment of students' life skills, the construction of harmonious relationships with peers and their transformation through adulthood, so that they can be ready to undertake the role of active citizen in society. This paper attempts to describe a collaborative project concerning three research areas as three separate studies: resiliency, peer mediation and citizenship education. The project consists of teaching interventions which were orchestrated for the infusion of the above components in the school curriculum aiming at students' emotional and conflict resolution skills as well as the promotion of their democratic role. Students of primary and secondary education from preadolescence to the culmination of adolescence participated in the project. Research findings suggest that school should focus on factors relating to students' emotional and social development which may successfully set the stage for improved academic performance and a responsible, democratic role towards society. These objectives are aligned with the principles of Critical Pedagogy focusing on students' emancipation, the acquisition of a values set and their readiness to act in the direction of common good equipped with critical thinking skills, empathy, and respect towards divergence. 


\section{Introduction}

The ongoing instability of worldwide socioeconomic conditions seems to raise a red flag regarding school's role since it is claimed that individuals as social beings live in interdependence with each other. In other words, wellbeing in societies is not merely a personal issue but is rather based on the formation of relationships and common efforts (Veugelers \& de Groot, 2019), so that individuals can feel and be responsible while acting for the benefit of society and humanity as a whole (Dimitriadou, Psoma \& Pnevmatikos, 2018). This perspective emphasizes school's role in the direction of preparing students for the current and their future life through adulthood. In detail, school should offer students the opportunity to be equipped with skills that can assist them in the direction of facing the perplexity and challenges of society nowadays (Claxton, Costa \& Kallick, 2016). This is the reason why emphasis should be placed on students' soft skills such as communication and problem solving. This way, school should focus on interventions and reformed curricula that aim at students' development in light of soft skills (Heckman \& Kautz, 2012).

According to a modern approach of the Aristotelian moral and political theory, as it is stated by Davidson, Lickona and Khmelkov (2008) in their study 'Smart \& Good High Schools', education should foster character formation. This may potentially be interpreted as the definition of educational aims targeting students' moral and emotional development in combination with their socialization and active participation in the school community. Therefore, this is probably the way that students can be also prepared for their future role in the social and political life of the community and the world. This idea is recapitulated in the notion of school not only embracing knowledge acquisition and cognitive skills but also promoting the cultivation of values and morality in school settings (Patry, 2012).

In line with the above, teaching process is characterized as dialectical and school is approached as a cultural framework towards students' empowerment and self-transformation (McLaren, 2003, pp. 69-70). In light of Critical Pedagogy, teachers should design and apply educational practices that promote skills correlating with responsibility and self-determination while they simultaneously acknowledge school's important role in the society as a factor which highlights freedom and democracy (Giroux, 2019). This way, students are offered the opportunity to cultivate respect, critical thinking and problem-solving skills which can lead to responsible decision-making when it comes to moral dilemmas (Dimitriadou, Vrantsi, Lithoxoidou, \& Seira, 2019). These practices may be infused to every school subject as an integral part of the school culture (Pnevmatikos \& Christodoulou, 2018; Seira \& Dimitriadou, 2017) and thus teachers can be facilitated in orchestrating their class in light of this twofold purpose; that is combining content based knowledge with values.

\section{Description of the project}

A research project aiming to provide innovative approaches in the current curriculum was designed and applied, so that concepts of social and emotional learning and democratic pedagogy could be integrated in a variety of school subjects. Under the guidance of three researchers of the University of Western Macedonia, Greece, it has involved three research areas corresponding to the following levels: a) pupils' empowerment regarding resilience, b) peer mediation with the aim of ameliorating students' relationships with their peers and c) citizenship education through which students' perspectives as members of society are in the limelight. Besides the initially set educational goals, the project simultaneously aimed at delving into students' needs initiating from themselves as autonomous units, their interaction with the circle of friends/peers and finally expanding to their perspective for society. 
Additionally, the project stands as a multifaceted study which focused on the reference groups (teachers, students and their parents) of each participating school combining qualitative and quantitative research methodology for in-depth analysis and interpretation. However, this paper focuses on students as participants.

Researchers initially traced students' existing needs in order to successfully design and apply teaching interventions in classes of 8 elementary schools -6 for resilience and 2 for peer mediation-, as well as in 3 classes of different types of Lyceums for citizenship education. It should be noted, though, that student participants differed in each research area, since each one was conducted separately to different population. The reason for this variation lies in the rationale that each research area aimed at different ages for the optimum application of the teaching interventions. Furthermore, in order to secure the effectiveness of the project as a whole, it was considered that each research area should refer to different student population, in the sense that students who participated in the project could cover a broad age range, with those of resilience and peer mediation being at the early stages of preadolescence and those of citizenship at the culmination of adolescence (Dimitriadou, Vrantsi, Lithoxoidou \& Seira, 2019).

\section{The teaching interventions in light of a common framework}

The teaching interventions -also applied separately to schools corresponding to each research area- attemped to follow the principles for students' personality empowerment as these have been stated since the 1980s (Joyce, Weil \& Calhoun, 2015) (for resilience), the improvement of students' moral and cognitive development in light of conflict resolution and the acquisition of life skills on the part of students (for peer mediation), so that they can be prepared to act as moral citizens with democratic awareness and respecting human rights (for citizenship education). In detail, for resilience, students were introduced to concepts relating to empathy and emotional awareness in combination with compassion and responsibility in terms of promoting positive classroom climate (Meiklejohn et al., 2012). For peer mediation, special emphasis was placed on communication and active listening as well as on empathy (Eisenberg, Eggum \& Di Giunta, 2010) and prosocial behaviour (Williams, O' Driscoll \& Moore, 2014). As far as it concerns citizenship education, the intervention was enriched in the direction of students approaching and understanding concepts related to society and interaction, action and social engagement, as well as their role as future citizens (Johnson \& Morris, 2010).

Although each research area aimed at achieving different educational goals, a common framework was followed in light of modern pedagogy aiming at a student-centered approach, so that students could feel active and adopt a responsible role in classroom settings (Nair, 2014). This aim was realized through experiential learning (Kolb, 2015), so that students' life skills could be developed. There was a variety of activities infused in the curriculum focusing on the initially set educational goals. All activities were developed based on modern teaching methodology aiming at motivating students and actively engaging them in the teaching procedure to achieve the optimum effectiveness of the project. They were designed in congruence with the students participants' needs and drew on the theory of differentiated instruction (Landrum \& McDuffie, 2010), authentic learning, role-play activities (Rao \& Stupans, 2012), moral dilemmas (Weinberger, Patry \& Weyringer, 2017), dialogue, students' experience, and the use of technological and art means. The students were often engaged in learning communities, in the direction of thorough understanding and constructing knowledge. It should be also noted that for every research area of the project a written consent 
of the parents/guardians' participants was obtained for the ethical conduct of the current research.

In line with the above, the project aimed to substantially act in the direction of promoting the notion of 'pluriverse' of the New Age; meaning that students can equally participate in constructing knowledge in school settings being aware that reality is defined in a versatile manner and multiculturalism stands against traditional perceptions' of worldwide homogeneity. This is probably the means that school can be democratized focusing on respect and pluralism (Katsarou \& Sipitanos, 2019).

\section{Resilience}

\section{Background}

It is considered that the financial condition in Greece has caused negative experiences for students who are aware of and unavoidably are connected with the financial problems their families experience. The aftermath of this condition leads to income insecurity and poverty, which in combination with social inequality and exclusion potentially results in psychological instability to part of the population and, therefore students are also negatively influenced. For students to be supported in this turbulent time, resilience should be developed through cooperation and understanding in the school classroom (Tepovich, 2012). Henderson (2013) described six factors which should be integrated in the teaching procedure as resiliency-building conditions constructing the resiliency wheel: increasing prosocial bonding, setting clear, consistent boundaries, teaching life skills, providing caring and support, setting and communicating high expectations, providing opportunities for meaningful participation (p. 25). By applying the first three factors, reduction of riskiness can be promoted while the last three potentially stand as preventative factors.

Additionally, according to Doll, Brehm and Zucker (2014) when resilience is promoted in classroom settings, students can act autonomously being characterized by self-efficacy, selfcontrol and improved academic performance. These elements are reflected to classroom climate and to the social interaction between teachers, students, and their families.

Based on this rationale, the first study of the project aimed at empowering resilience in students who exhibit problematic behavior due to family conditions related to financial problems. The researcher closely cooperated with the teachers of every classroom in light of action research in order to design and apply teaching interventions in the direction of emotion management, emotional intelligence and self-esteem. At the first stage of the study, students exhibiting behavior indicating a low resilience profile with antisocial behavior, social isolation, emotional swings, depression, lack of concentration and indolence (Vrantsi \& Dimitriadou, 2015) were selected under the guidance of their teachers while at the second stage of the study, teaching interventions were applied in the classroom settings during an academic year. Students participated in semi-structured interviews before and after the teaching interventions. The research questions set were the following:

- To what extent and in what way are students influenced by the conditions caused by the financial crisis?

- To what extent and in what way can the teaching intervention empower students' resilience so that financial crisis consequences can be mitigated? 


\section{Method}

\section{Participants}

Eleven students exhibiting a profile of lower resilience from the fourth (3 students), fifth (4 students) and sixth (4 students) class of 6 primary schools of Western Macedonia participated in the project.

\section{Measure}

A semi-structured interview focusing on the six resiliency-building conditions was utilized for the first study of the project which was based on current literature. A set of questions was constructed for every condition of the resilience wheel: a) provide opportunities for meaningful participation (e.g. What do you think that will help you stay focused on the lesson?), b) increase prosocial bonding (e.g. Is there a person who can help you solve your problems? If yes, how?), c) set clear, consistent boundaries (e.g. Do you participate in setting rules in class?), d) set and communicate high expectations (e.g. Do you feel that you can achieve your goals?), e) provide caring and support (e.g. Are you interested in acting in a way so that you can be admired by your classmates?), f) teach life skills (e.g. Do you fight with your classmates?) (Henderson, 2013, p. 25).

\section{Data Assessment}

Collected data from the semi-structured interviews were assessed according to the method of content analysis. Students' answers before and after the intervention were coded on the basis of the six resiliency-building conditions. Elements correlated with the aforementioned conditions were detected in the students' answers following the deductive approach (Graneheim, Lindgren \& Lundman, 2017), while two research assistants classified $20 \%$ of participants' answers regarding the categories. According to Cohen's kappa, the interrater agreement was moderate (pre-test stage: $\kappa=0,65(95 \% \mathrm{CI}, 0,39-0,91), \mathrm{p}<0,001$. and post-test stage: $\kappa=0,66(95 \% \mathrm{CI}, 0,42-0,90), \mathrm{p}<0,001)$ and reached the level of $100 \%$ after further discussion with the authors.

\section{Results}

Meticulous reading of the students' interviews indicates that whether they exhibited elements of resilience in the initial interviews or not, they seem to have acquired more behavioural patterns which are correlated with this particular notion.

\section{Increase prosocial bonding}

Before the teaching intervention, students did not recognize positive role models in school. When asked about their interest in school activities, they were partially or not at all interested in school activities and academic performance. They felt that no teachers or peers cared about them and did not mention any assistance in problem solving ('No. My parents. I only fight with my siblings. Alone or with our parents but not at school. My parents tell me their opinion and what is right, and we choose.' Boy, 6th Grade) while they also claimed that other classmates sometimes inhibited their problem-solving efforts. More particularly, one student stated that no classmate helped them at school while three of them mentioned that help was offered by family.

After the teaching intervention, all students seemed willing enough to achieve and pursue 
satisfying academic performance. They supported the idea that they cared about school activities and had positive role models while they seemed to believe that there were no individuals who may have complicated their problem solving efforts since there were people who cared about and supported them when it came to problem solving ('There is my family and then my teacher and my friend. We discuss and reach a conclusion.' Boy, 6th Grade).

\section{Setting clear, consistent boundaries}

When asked about rule setting in their classroom and school in general, before the teaching intervention, all students seemed to believe that school and classrooms rules were necessary, and they actively participated in their setting. However, they assigned the role of the protagonist to the teacher ('We all suggest some rules so I participate in setting them...but the teacher usually sets the rules, and we should follow them.' Girl, 5th Grade).

After the teaching intervention, all students held the same perspective regarding the rules' necessity and setting but articulated on this idea exhibiting responsibility and awareness (' $W e$ discuss with my classmates and our teacher and we set the rules. There should be rules because in this way we behave better, we have dignity and we also respect each other.' Girl, 5th Grade).

\section{Teaching life skills}

Students seemed to get stressed really easily and tended to be susceptible to conflicts with their classmates. They admitted embracing their classmates' opinion despite their disagreement ('Yes, I agree with my classmates because they are right.' Boy, 6th Grade).

After the teaching intervention, students' susceptibility to stress was significantly reduced and some of them claimed that they rarely tended to proceed to conflicts with their classmates ('Not really easily, I don't fight easily.' Boy, 6th Grade), while building a good relationship with them. It is worth noting that 9 students had mentioned stress before the intervention, while after the intervention 3 of them stated that they do not get easily stressed with the rest mentioning that they feel stressed only under certain circumstances; however, they are capable of handling their feelings. They also seemed to believe that they were not to follow a friend's opinion if they disagreed with it ('If they told me to steal from something then I'd simply disagree and try to advise them.' Boy, 6th Grade).

\section{Providing caring and support}

In the initial semi-structured interviews 8 students believed that they were important to their class and 7 desired to be admired by their classmates without, however, assertiveness or understanding the reasons for this statement ('I don't know (if I am important to my class), maybe. We all are...I don't know. 'Boy, 6th Grade).

In the post-interview, 10 students claimed their importance as human beings and members of their class and expected their peers' admiration with clear argumentation: ('Yes, I feel important to my class. Every child is important in a class and I am, too.' Boy, 6th Grade).

\section{Setting and communicating high expectations}

Before the teaching intervention, 9 students believed that they set realistic goals which they could achieve while 8 of them felt that their abilities were rewarded by other individuals ('I don't know...I think they are (rewarded). ' Boy, 6th Grade). 
After the teaching intervention, all students believed that they could achieve their goals and felt rewarded for their abilities ('Yes, my teacher told me about my strong characteristics. My dad knows that my siblings are good at football and he knows that I have certain abilities and so do my friends.' Boy, 6th Grade).

\section{Providing opportunities for meaningful participation}

Before the teaching intervention, all students seemed to be responsible and actively participated in school activities while 6 of them were rarely or sometimes concentrated on the lesson. Regarding their perception of the teaching conditions which promote concentration, 5 of them claimed that students, themselves, were the main factor and only one of them indicated the teaching procedure as such. The rest of the students recognized a combination of the teaching procedure and students, gaming deprivation and the teacher or the school director as factors promoting concentration ('Lessons are really interesting... we learn a lot of things about our world.' Boy, 6th Grade).

After the teaching intervention, 8 students claimed that they could focus on the lesson recognizing themselves, the teacher and/or the lesson as a promoting concentration factor. All individuals took responsibility for their actions and participated in school activities (' $I$ wouldn't blame somebody else if I did something wrong. ' Boy, 4th Grade).

\section{Discussion}

Students seemed to have acquired or improved certain behavioural patterns correlating with resilience which are majorly organized in two broad categories referring to a) themselves, interpersonal relationships and socialization and b) their crystallized opinions about school organization and the opportunities offered by it. In detail, regarding the first category, they seem to have constructed prosocial bonds with at least one person (teacher, classmate, friend) who they claim that they care about, support and encourage them in the direction of problem solving through discussion while providing mutual assistance. Constructing social relationships and emotional bonds is considered as a fundamental human need (Baumeister \& Leary, 1995), while it also acts as an important protective factor regarding resilience (Alvord \& Grados, 2005).

They also discovered positive role models in their circle of friends, and they are willing to adopt qualities regarding their academic performance and behaviour by accepting and embracing their personal abilities and potential. Their social skills ameliorated since they form positive relationships with their classmates, choose peaceful conflict resolution, act autonomously and deploy critical thinking strategies before embracing their peers' opinions. Their emotional well-being is also stated by their ability to control stress levels and recognize themselves as important members of the community. Correspondingly, students seem to expect equal recognition by their peers and try to respond to high expectations, by trusting their own abilities of achieving goals. According to Woodhead's research (2004), children's socioemotional and moral development focusing on self-esteem and personal wellbeing seems to significantly rely on the extent to which they understand their social status and capabilities while they are offered the opportunity for inclusion in groups.

Regarding the second category, students seem to find school activities interesting and pleasant since these can lead to advanced reasoning, intelligence, socialization, and a future career. A similar action research study (Bleach, 2015) indicated students' interest for activities in the classroom through which they feel satisfied and willing to participate in. 
All students participate in rule setting while they support their necessity as a preventative means against impunity, disorder and aggressive behavior while setting the stage for safety conditions, behavioral improvement and positive classroom climate. They seem to believe that they are offered the opportunities for meaningful participation in the school activities and feel responsible to this end. In case of lacking concentration on the lesson, they are aware of the reasons which contributed to their indifference, stating that these may be conversations with their classmates, subject's monotony, hunger, or poor studying. They can also proceed to suggestions for this condition to be improved by action on part of the teacher through seats rearrangement or the application of more interesting activities. According to Angelkovski (2016), the sense of belonging in the school community is facilitated by rule setting and classroom routine, a finding that seems to verify the findings of this study.

\section{Peer Mediation}

\section{Background}

Violence in school settings is usually considered as a social problem which significantly influences students' academic and psychological development, while it simultaneously undermines democratic values which should be dominant in modern schools (Smith, 2004). Since violent incidents in school settings and violent representations in families and society are increasing, students tend to familiarize themselves with this behavior, considering violence as socially accepted. Peer mediation can be a preventative means for conflict resolution in school, since in case of escalation these conflicts may lead to violent outbursts and bullying (Ananiadou \& Smith, 2002), with serious psychosomatic consequences for the students (Dinkes, Cataldi, Lin-Kelly \& Snyder, 2007). Through educational programs focusing on peer mediation, students can be equipped with skills such as active listening and cultivate empathy (Compton, 2002), while they can be also introduced to anger management techniques and conflict resolution skills with emphasis on the notions of racism and sexism avoidance even from primary school (Cowie \& Hutson, 2005).

The second study of the project aimed at applying and evaluating a Peer Mediation program in school settings. The teaching intervention was designed in order for students to cultivate conflict resolution skills so that they could autonomously be led to conflict resolution without an adult intervention while simultaneously acting against bullying and school violence. In the first stage of the study, students' needs regarding conflict were traced with emphasis on their approaches to it. After the initial tracing, the cross-curricular teaching intervention was applied to a variety of school subjects and lasted for twelve teaching hours. After the intervention, students were invited to evaluate the project by completing a post-questionnaire consisting of open and closed ended questions.

The research questions set were the following:

- To what extent can primary school students be familiarized with skills of conflict resolution and peer mediation?

- To what extent can a peer mediation program lead students to behavioural change regarding conflict both inside and outside school settings? 


\section{Method}

\section{Participants}

One hundred and seventeen (67 boys and 50 girls) fourth and fifth-graders of two primary schools of Western Macedonia participated in the study. Students of fourth and fifth grade were selected as suitable for disseminating the new conflict resolution technique in the school community, since it was considered that fourth graders could more easily approach younger students, while fifth graders could cooperate better with the older ones.

\section{Measure}

Students were invited to answer a pre-test questionnaire with closed-ended questions at the beginning of the project. This questionnaire included five vignettes with realistic conflict scenarios. Students were given information about the protagonists' names, age, and class, so that they could identify themselves with them, and were asked to choose the preferable way of resolving or dealing with each conflict. The vignettes were constructed so that students' answers could be linked with their strategies for resolving conflicts, namely problem-solving and communication, aggression including physical violence, avoidance and/or withdrawal (Crawford \& Bodine, 1996). One of the vignettes describing a bullying incident included an item regarding the concept of protection, so that students' moral reasoning regarding care (Gilligan, 1977) could be examined. The post-test questionnaire included the five vignettes used in the pre-test stage and a set of four closed-ended questions in which students expressed their agreement with the given statements (e.g. I can solve conflicts with my classmates more easily.) by choosing between items labelled as I agree or I disagree. Seven open-ended questions focusing on conflict resolution and school climate (e.g. Do you think that you care more about your classmates?) were also included. In these questions students were also asked to describe an incident which happened at school and offered them the opportunity to apply the skills potentially acquired from the program (Describe an incident when you recognized your classmates' emotions in a better way). The use of questionnaires facilitated the needs of approaching a large number of participants (McGuirk \& O’ Neil, 2016) during the rigid school timetable.

\section{Data Assessment}

Content analysis approach was utilized to assess the data of the second study. The categories were constructed through students' answers without definition in advance. During this coding phase, it was observed that certain conceptual patterns emerged in every question following the inductive approach (Graneheim, Lindgren \& Lundman, 2017). Therefore students' answers were coded in 5 major categories: a) Emotion Recognition describing the way students are able to recognize their own and their classmates' emotions; b) Peer mediation and conflict resolution referring to the skills students acquired in this domain during the intervention; c) Positive Social Behaviour which correlates with violence avoidance in school settings; d) Moral Elements which involves concepts of justice, care and prosocial behaviour and e) Promoting positive classroom climate, which refers to students' interest about their cooperation and class. Two research assistants also classified $20 \%$ of participants' answers into the aforementioned categories and Cohen's kappa determined that the inter-rater agreement was substantial $(\kappa=0,77(95 \% \mathrm{CI}, 0,56$ to 0,98$), \mathrm{p}<0,005$.) and reached the level of $100 \%$ after discussion with the authors. 


\section{Results}

Given the use of the particular questionnaire for this research area, findings were analyzed separately applying both quantitative and qualitative approaches for contextualized understanding. In detail, the closed-ended questions of the questionnaires were examined quantitatively while the open-ended questions followed the qualitative methodology of content analysis.

\section{Comparison between pre and post-test questionnaire vignettes}

Students' pre- and post-test answers in the vignettes were compared with the use of McNemar's test. The test determined that a statistically significant difference was identified in students' answers before and after the teaching intervention in the first, second and fourth vignette $(\mathrm{p}<.05)$. For the first vignette before the intervention, 81 students $(69.2 \%)$ selected the item correlated with problem solving (Item a: They should discuss and try to find a solution), while after the intervention the proportion was increased with 103 students (88\%) selecting it $(\chi 2=11.605)$. For the second vignette, before the intervention, 21 students (17.9\%) selected the item referring to problem solving (Item c: She should apologize and try to explain her emotions to her friend), while after the intervention 69 students (59\%) chose this answer $(\chi 2=32.485)$. In the fourth vignette, students' answers focused on two answers. Before the intervention only 8 students $(6.8 \%)$ chose the item which correlates with asking help from another person (Item a: They should inform their teacher about the event) in the problem solving category while after the intervention 68 students $(58.1 \%)$ selected it $\left(\chi^{2}=\right.$ 52.742). Since this vignette narrated a story of a bullying incident, the item mentioning the harassed peer's protection was also offered (Item c: They should help their classmate and not allow other girls to treat her this way). Before the intervention only 22 students $(18.8 \%)$ selected this answer while after it, the proportion was increased to 61 students $(52.1 \%)\left(\chi^{2}=\right.$ 23.672).

\section{Post-test questionnaire closed-ended answers}

For this part of the post-test questionnaire, the four closed-ended items where students stated agreement or disagreement aimed at tracing the effects of the intervention on a) their emotional expression (item 4), b) recognition of classmates' emotion (item 6), c) care for the class climate (item 8) and d) the construction of positive relationships in classroom settings (item 10). The largest proportion of students expressed their agreement with the aforementioned statements, while a small percentage did not answer these questions. Their answers' frequencies are included in Table 1.

Table 1. Students' frequencies and percentages regarding items 4, 6, 8 and 10 of post test

\begin{tabular}{lllllllll}
\hline & Item 4 & & Item 6 & & Item 8 & \multicolumn{2}{c}{ Item 10} \\
& Frequency & Percent & Frequency & Percent & Frequency & Percent & Frequency & Percent \\
\hline I agree & 99 & 84.6 & 93 & 79.5 & 99 & 84.6 & 94 & 80.3 \\
I disagree & 13 & 11.1 & 21 & 17.9 & 13 & 11.1 & 15 & 12.8 \\
No answer & 5 & 4.3 & 3 & 2.6 & 5 & 4.3 & 8 & 6.8 \\
Total & 117 & 100 & 117 & 100 & 117 & 100 & 117 & 100 \\
\hline
\end{tabular}

The findings from the close-ended questions probably indicate that the biggest percentage of students were able to express their feelings and simultaneously be aware and understand their classmates' feelings at the school setting. Additionally, they seem ready to adopt a responsible role in terms of protecting and safeguarding a positive climate in their classroom 
and the school as a community exhibiting care towards others while at the same time constructing harmonious and cooperative relationships.

\section{Post-questionnaire open-ended questions}

Regarding the open-ended questions, students' answers were coded in five main categories (see Data Assessment in Peer Mediation section). In detail, students' answers indicated that they tended to elaborate on the questions asked referring to certain and recurrent conceptual patterns as these were traced and coded.

Emotion Recognition. Students claimed that they could recognize their own and their classmates' emotions in a better way after the intervention. They stated that certain techniques were activated in this direction since they could trace elements of body language, assess the importance of a situation, and make logical assumptions regarding other people's emotions:

I think that I can recognize other people's emotions but also mine because now I know what is going on with other people. It is much easier than before, and I know how to handle this situation. (Girl, 4th grade).

Peer mediation and conflict resolution. Students stated that peer mediation was valuable in the direction of conflict resolution, admitted that the teaching interventions contributed to the development of skills as such and felt proud of their role as mediators in the school community ('Yes because this program helped me resolve my conflicts in a peaceful way.' Girl, 5th Grade). Additionally, they claimed that Peer Mediation assisted them in decision making ('Yes because after the Peer Mediation program, if I fight with someone, we can be friends again.' Boy, 4th Grade).

Positive social behaviour. Students considered the teaching intervention as beneficial since it allowed them to believe that they exhibited positive social behavior with violence avoidance. They also understood the catastrophic consequences of physical or verbal violence. Moreover, they applied anger management techniques while being ready to apologize ('Yes because we have learnt that we should not hit or push each other and now we don't do this thing to the people who we fight with.' Boy, $4^{\text {th }}$ Grade).

Moral elements. Students seemed to elaborate on moral elements by being supportive in the direction of conflict resolution ('Two children from the $4^{\text {th }}$ Grade were fighting and I went to break up the fight and help them.' Boy, $5^{\text {th }}$ Grade). The concept of care and effort to help focusing on prosocial behavior also emerged in their answers, since they cared more about common good of their classroom and school community in general ('I think this (program) will be useful for the rest of our lives because something may happen in front of us and then we can help.' Girl, $4^{\text {th }}$ Grade). They particularly emphasized the concept of justice since they interpreted it as a fundamental element in their relationships trying to remain impartial even for their close friends ('I always care about justice.' Boy, $4^{\text {th }}$ grade).

Promoting positive classroom climate. Students claimed that they tried to safeguard positive classroom climate after the teaching interventions. They also expressed their respect to values such as cooperation in classroom settings while claiming that their relationships with the other classmates ameliorated; thus climate was improved through friendly bonding ("Now I can cooperate more easily with my classmates.' Boy, $5^{\text {th }}$ Grade). 


\section{Discussion}

Qualitative data findings potentially indicate that the application of the teaching intervention significantly contributed to the creation of a positive school climate; interestingly, students stated that they care more about the protection of their class and classmates in case of conflicts.

This safe learning environment can also enhance students' moral development as they are more aware of their emotions while managing them in a better fashion, avoiding violent outbursts. As a result, they are led to responsible decision making. This finding is in congruence with the findings of Turk's research, according to which teaching peer mediation in school settings can be of major importance when it comes to violence prevention; as a result, introducing these programs to school culture may prove to be a valuable tool for students' development (2017). Students' social and emotional learning was also promoted as they stated 'self-reported prosocial behavior' (Jones, 2004, p. 239). This result is highlighted since they are willing to help and intervene for conflict resolution whether this refers to their classmates, friends, or relatives. In that way school can highly contribute to this direction while safeguarding the development of future generations. Students' social and emotional development may also set the stage for improved academic performance, positive behaviour, and reduced stress (Durlak, Weissberg, Dymnicki, Taylor \& Schellinger, 2011).

They seem to have acquired conflict resolution skills which can also promote a 'constructive conflict community' (Jones, 2004, p. 234), where bullying events can be prevented or need to be tackled for the overall well-being of the class and the school. In line with the above rationale, conflicts are addressed as an opportunity for better relationship construction in the context of understanding, tolerance, empathy, and justice. This is probably the case since according to the research of Şahin, Serin \& Serin conflict resolution and peer mediation may lead to significant improvements regarding the participants' empathic skills (2011). Therefore, cultivating students' empathy can infuse understanding in the school community, a fact which contributes to conflicts resolution in a constructive way.

All these elements with the notions of care and justice being particularly emphasized seem to indicate that students' emotional development was promoted and that the combination of a conflict resolution education program can hopefully lead to findings as such.

\section{Citizenship}

\section{Background}

Nowadays civic participation -especially on the part of young people- is decreased because citizens do not seem to trust politicians and political parties; however, their participation is of paramount importance for democracy (Print \& Lange, 2012). Due to this fact, over the last decade democratic countries have emphasized citizenship education (Duggan, 2015; Petrik, 2013). Despite these efforts, schools seem to fail in applying teaching techniques in this direction. In Greece, for example, curriculum is characterized as excessively loaded and knowledge orientated. This is especially the case in Lyceum, where students should be actively prepared for their imminent roles as adults with rights and responsibilities. However, the educational system at this level rather stands as an academic threshold for Higher Education. Teachers, on the other hand, strive to deal with the material offered and in this way, they are quite often incapable of delving into concepts of citizenship and values (Veugelers, de Groot \& Stolk, 2017). However, they should be aware of the 
twofold nature of their role by not only acting as mediators between students and knowledge but also as role models of ethos and behaviour (Alt \& Reingold, 2012). If in current democratic societies, human rights, tolerance, respect, solidarity, and critical thinking are the milestones, then schools should be holistically transformed into democratic communities. School life organisation, teachers' behaviour and the promotion of values through several school subjects are integral parts of citizenship education.

Based on this rationale, the third study of the project aimed at promoting citizenship education at Lyceum settings through action research. In detail, the researcher cooperated with teachers in 3 Lyceums in order to apply cross-curricular teaching interventions for an academic year. The teaching interventions deployed strategies based on cooperation, empathy, cultural sensitivity, and awareness, while the values of democracy were emphasized. Simultaneously, authentic learning was particularly emphasized so that students' needs could be addressed through their experiences and intrinsic motivation could be developed (Herrington, Reeves \& Oliver, 2014). A number of selected students from every school participated in focus groups before and after the interventions.

The research questions set were the following:

- Which aspects of citizenship education can be promoted through actions of typical and non-typical educational form?

- To what extent can citizenship education promote students' democratic ethos?

\section{Method}

\section{Participants}

Six first grades of Lyceum were selected from every school participating in the study (18 students). Students participants were selected on the basis of their teachers' assessment regarding their academic performance, as well as their social and emotional skills which were expected to enable them to represent their class and elaborate on citizenship.

\section{Measure}

During the first and final focus group, students were asked to elaborate on questions which were separated in two categories according to relevant literature. In the first category (five questions), students' perceptions regarding their school life, cooperation, rules, and activities were traced (e.g. Do you feel satisfied with your life in school until now?). In the second category (five questions), students' beliefs about democracy, citizenship and their proposals regarding preparation for their future life in a democratic society came to the limelight (e.g. What comes to your mind when you listen to the word 'democracy'? How would you define a democratic citizen?).

\section{Data Assessment}

Following the content analysis method, students' answers were coded without previously defined categories. According to conceptual classification, four major categories arose in students' answers before and after the intervention: a) Positive emotions for school, b) Students' perceptions regarding the teachers' role, c) Opportunities for cooperation and d) Students' perception of rules in school settings. Before coding completion, two research assistants classified $20 \%$ of participants' answers into the particular categories. Cohen's kappa determined that the inter-rater agreement was moderate (pre-test stage: $\kappa=0,67(95 \%$ 
CI, 0,44 - 0,90), $\mathrm{p}<0,001$. and post-test stage: $\kappa=0,50(95 \% \mathrm{CI}, 0,24-0,76), \mathrm{p}<0,001$.$) and$ reached the level of $100 \%$ after further discussion with the authors.

\section{Results}

The following findings focus on four categories as they were coded through a 'bottom-up' process.

\section{Positive emotions for school}

Regarding the first category, in the focus groups carried out before the intervention, students claimed that positive emotions were correlated with projects of experiential learning, school activities and trips ('The activities which we do during the programs are equally pleasant to a good grade.' Boy, 1st Grade) while they mentioned that school grades and assessment could cause stress.

Human relationships in school settings also seemed to highly contribute to positive or negative school emotions. In detail, socialization and friendships between peers were mentioned by students ('What I like most in school is our friendships. I mean that we spend time all together during breaks and we become more sociable.' Boy, 1st Grade).

Only some of the students claimed that they experienced positive emotions when they could trust their teachers who supported them by expressing their interest and love ('Feeling that your teachers are close to you and being able to trust them about some issues is a very good thing.' Girl, 1st Grade).

After the intervention, in one of the three Lyceums participating in the research, students mentioned that they felt more satisfied when they worked in groups with experiential activities. In the other two schools, the majority of students placed emphasis on their relationships ('Teachers showed more interest, the classroom climate was more pleasant and generally speaking, things were really improved in comparison to junior high school.' Boy, 1st Grade).

They claimed that they were pleased with the lesson carried out in a more explicit way with the use of projects, since they believed that they could form their own opinion and share their concerns ('This is the first time that I have noticed that my opinion really counts, the lesson is explicit and free and it also includes more things than just the mandatory teaching material.' Girl, 1st Grade).

\section{Students' perceptions regarding the teachers' role}

Regarding the second category before the intervention, students seemed to agree that teachers should be inspiring, act as a role model and that their attitude teaches a way of thinking while they should not be strictly restricted to the teaching process ('You should feel happy when you have a certain teacher for a subject; you should feel good with them.' Girl, 1st Grade).

Students after the intervention seemed to be more aware of the idea that teachers should be inspiring for their students. They recognized the attachment created between themselves and their teachers during the intervention and the fact that cooperation with them during excursions, field trips and various activities could significantly contribute to life lessons ('Our relationships at school are friendlier and this is a good thing...Promoting students' diligence 
should be a priority for teachers' Girl, 1st Grade).

\section{Opportunities for cooperation}

Regarding the third category, students also supported the idea that school offers some opportunities for cooperation. This is mainly achieved through the various programs and activities that are being developed in an expanded field of subjects but the responsibility of promoting cooperation lies in teachers' hands ('School offers opportunities for cooperation but students should be willing to search for them and teachers should appropriately inform them.' Boy, 1st Grade).

After the intervention, students believed that cooperation was significantly promoted. In the second school, students added that when sociological, emotional and moral elements were promoted in the school settings, academic performance was also improved ('School actually promotes interaction between students and teachers and fosters values...this is something that also influences cognitive skills.' Girl, 1st Grade).

In the third school, students also admitted that they were surprised by the extent of cooperation they had during the teaching intervention ('We were all surprised by the cooperation we had this year...it was important... We had never had such an experience before.' Boy, 1st Grade).

\section{Students' perception of rules in school settings}

For the fourth category, before the intervention, students agreed that there should be rules which they should respect in school settings. They also claimed that not following rules leads to confusion, especially when teachers act likewise. When asked about the person responsible for setting these rules, most of the students referred to the Ministry of Education, the school director, and the teachers. Students added that up to an extent, students' representatives should also participate in rule setting ('Some students from the school community should participate, I mean in cooperation with the teachers.' Girl, 1st Grade).

After the intervention, students believed that participation of students in cooperation with the school director and the teachers is of paramount importance in rule setting. These rules may be initially designed by the Ministry of Education and should be adapted to each school's needs through cooperation, so that all students can feel committed to and be capable of respecting them ('Students should participate in rule setting and these rules should be also followed by teachers because some of them do whatever they want.' Girl, 1st Grade).

\section{Discussion}

Collected data enabled comparisons between students' answers before and after the intervention in which common elements as well as differentiations can be traced. In every case, the teaching intervention seems to have influenced students' attitude towards the educational process since the values of cooperation, friendship and trust were enforced and students' positive emotions for school were increased. It is worth mentioning that students seem to recognize school's contribution in the formation of friendly relationships and as -it was indicated-teachers' respect for the students' opinion along with the promotion of critical thinking generally cultivated their moral reasoning. Students also seem to have realized the significance of teachers' role in their personality formation and they are willing to participate in common experiences such as field trips, which can lead them to life skills acquisition. 
Since cooperative learning was a fundamental element in the intervention, the data probably indicate that the positive emotions experienced through a pleasant teaching procedure may cultivate certain qualities and positively affect students' motivation, so that better academic performance will flourish. Finally, the fact that school as a community prepares students for their future role as citizens is emphasized, since the intervention aimed at promoting students' democratic ethos. Students' proposal to actively work in rule setting with teachers and the school director points out their awareness regarding all community members' responsibility and participation in decision making, a condition that cultivates a feeling of commitment. This way, if school literally acts as a democratic community, it is likely to promote active citizenship.

As John Dewey (1966) has stated from the early years of the 20th century, school stands a microcosm for society which should holistically approach students while acting in a democratic way which will form democratic personalities for the future. Today the findings of this research seem to correlate with other studies of modern literature which support the idea that societies may successfully face 21 st century challenges by actively promoting democracy in the school setting. This is the reason why school should not only focus on cognitive skills but also promote the emotional, moral, social and political development of children and adolescents (Dimitriadou, Psoma \& Pnevmatikos, 2018; Veugelers, de Groot \& Stolk, 2017; Davidson, Lickona \& Khmelkov, 2008; Cohen, 2006). The findings of this particular research seem to indicate the positive outcomes that arise when school and teaching process work in this direction.

\section{General Discussion}

As the findings of the three studies probably reveal, students achieved life skills enhancement at a threefold level, regarding: a) themselves as individuals with resilience promotion, b) themselves and interpersonal relationships through the acquisition of conflict resolution skills and c) their perspective in terms of cooperation with teachers, understanding of the school's role and their will for active participation in it.

The data from the three research areas of the project probably indicate that orchestrated teaching in the direction of Critical Pedagogy can motivate students to their empowerment, while it simultaneously increases satisfaction from schooling and the school community. Interventions as such can be potentially applied from early school years for students to be offered the opportunity for self-determination, restoration of monolithic beliefs, tolerance towards others and responsible actions towards society. This way, students are expected to be capable of exploring and thoroughly understanding - by constructing their own knowledge through experience - that being a citizen requires personal struggle and cooperative action with other individuals (Oser \& Veugelers, 2008). In conclusion, it could be suggested that social and emotional skills as well as academic knowledge can significantly promote active participation in democracy; and this tendency, according to Cohen (2006, p.206), may cultivate a school climate that invests on security, care and cooperation among students as a central point for social justice.

\section{Limitations}

A first limitation of the aforementioned studies may be the particular educational approach to notions such as resilience that traditionally appertain to the scientific field of psychology. A potential combination of both fields may prove useful to be developed by other research in the future. Additionally, another potential limitation is the variation of 
participants' age which was selected in order to facilitate methodology issues, since the three researchers of the studies should approach and work in different educational levels, according to the needs of their research viewpoints. Despite these particular limitations, the research explores empirical data deriving from school reality which can potentially be utilized as reform means.

\section{Acknowledgement}

The project has been funded after assessment by the program Researchers Support with emphasis on New Researchers of the Greek Ministry of Education, Research and Religious Affairs and the European Social Fund (2018-2019).

\section{References}

Alt, D., \& Reingold, R. (Eds.). (2012). Changes in teachers' moral role: From passive observes to moral and democratic leaders. Rotterdam: Sense Publishers.

Alvord, M. K., \& Grados, J. J. (2005). Enhancing resilience in children: A proactive approach. Professional Psychology: Research and Practice, 36 (3), 238-245. https://psycnet.apa.org/doi/10.1037/0735-7028.36.3.238

Ananiadou, K., \& Smith, P. K. (2002). Legal requirements and nationally circulated materials against school bullying in European countries. Criminology and Criminal Justice, 2(4), 471-491. https://doi.org/10.1177\%2F17488958020020040501

Angelkovski, R., (2016). Resilience in children: Educational significance. Journal of Student Engagement: Education Matters, 6(1), 39-45. https://ro.uow.edu.au/jseem/vol6/iss1/6

Baumeister, R. F., \& Leary, M. R. (1995). The need to belong: Desire for interpersonal attachments as a fundamental human motivation [Electronic version]. Psychological Bulletin, 117, 497-529.

Bleach, J. (2015). Improving numeracy outcomes for children through community action research. Educational Action Research, 23 (1), 22-35. https://doi.org/10.1080/09650792.2014.994016

Claxton, G., Costa, A. L., \& Kallick, B. (2016). Hard thinking about soft skills. Educational leadership, $\quad$ March 2016. ssl.webflow.com/5b69a01ba2e409501de055d1/5e6b657d9bbe266b5800b6a5_Art\%20 Costa\%20and\%20Glaxton.pdf Retrieved on 9/5/2020.

Cohen, J. (2006). Social, emotional, ethical, and academic education: Creating a climate for learning, participation in democracy, and well-being. Harvard educational review, 76(2), 201-237. https://doi.org/10.17763/haer.76.2.j44854x1524644vn

Compton, R. (2002). Discovering the promise of curriculum integration: The national curriculum integration project. Conflict Resolution Quarterly, 19(4), 447-464. https://doi.org/10.1002/crq.3890190405

Cowie, H., \& Hutson, N. (2005). Peer support: A strategy to help bystanders challenge school bullying. Pastoral Care in Education, 23(2), 40-44.

Crawford, D., \& Bodine, R. (1996). Conflict Resolution Education. A Guide to Implementing Programs in Schools, Youth-Serving Organizations, and Community and Juvenile Justice Settings. US Department of Justice \& US Department of Education. Retrieved from:

http://preview.healthteacher.com/s3 handler/resources/content/teachersupports/conflic tguide_NCJRS.pdf

Davidson, M., Lickona, T., \& Khmelkov, V. (2008). Smart \& Good Schools: A New Paradigm for High School Character Education. In L. P. Nucci \& D. Narvaez (Ed.), 
Handbook of moral and character education (pp. 370-390). New York, Oxon: Routledge.

Dewey, J. (1966). Democracy and Education. An introduction to the philosophy of education. New York: The Free Press.

Dimitriadou, C., Vrantsi, A., Lithoxoidou, A., \& Seira, E. (2019). Teachers' critical thinking dispositions through their engagement in action research projects: An example of best practice. In M. Tsitouridou, J. Diniz, A. Mikropoulos, \& S. Chadjileontiadou (Eds.), Tech-EDU-2018, Communications in Computer and Information Sciences Series (CCIS), Vol 993. Springer, Cham, Part of Springer Nature, pp. 166-180.

Dimitriadou, C., Psoma, D., \& Pnevmatikos, D. (2018). Teachers' Discourses for Integrating Moral Issues in their Instruction. In B. Latzko, \& A. Weinberger Double Assignment in Teacher Education: A necessity to Address the Global Challenges. Menon 3rd Thematic Issue, 82-105. Retrieved from: http://www.edu.uowm.gr/site/system/files/menon_issue_3rd_special_112018.pd $\underline{f}$

Dinkes, R., Cataldi, E. F., Lin-Kelly, W., \& Snyder, T. (2007). Indicators of school crime and safety: 2007 (NCES No. 2008-021/NCJ 219553). Washington, DC: US Department of Education, National Center for Education Statistics. Retrieved from: https://files.eric.ed.gov/fulltext/ED499165.pdf

Doll, B., Brehm, K., \& Zucker, S. (2014). Resilient classrooms: Creating healthy environments for learning ( $2^{\text {nd }}$ Edition). New York: Guilford Publications.

Duggan, J. P. (2015). Citizenship education in Irish secondary schools: the influence of curriculum content, school culture and stakeholder perspectives. $\mathrm{PhD}$ Thesis, University College Cork. https://cora.ucc.ie/bitstream/handle/10468/2077/Thesis_Combined.pdf?sequence=4\&i sAllowed $=\mathrm{y}$

Durlak, J. A., Weissberg, R. P., Dymnicki, A. B., Taylor, R. D., \& Schellinger, K. B. (2011). The impact of enhancing students' social and emotional learning: A meta-analysis of school-based universal interventions. Child development,82(1), 405-432. https://doi.org/10.1111/j.1467-8624.2010.01564.x

Eisenberg, N., Eggum, N. D., \& Di Giunta, L. (2010). Empathy-related responding: Associations with prosocial behavior, aggression, and intergroup relations. Social issues and policy review, 4(1), 143-180. https://doi.org/10.1111/j.17512409.2010.01020.x

Gilligan, C. (1977). In a different voice: Women's conceptions of self and of morality. Harvard educational review, 47(4), 481-517. https://www.researchgate.net/profile/Carol_Gilligan/publication/253543593_In_a_Dif ferent_Voice_Women's_Conceptions_of_Self_and_of_Morality/links/540874320cf23 d9765b2aa79.pdf

Giroux, H. A. (2019). When Schools Become Dead Zones of the Imagination: A Critical Pedagogy Manifesto. In K.J. Saltman \& A.J. Means (Eds) The Wiley Handbook of Global Educational Reform (pp. 503-516). Hoboken: John Wiley \& Sons, Inc.

Graneheim, U. H., Lindgren, B. M., \& Lundman, B. (2017). Methodological challenges in qualitative content analysis: A discussion paper. Nurse education today, 56, 29-34. https://doi.org/10.1016/j.nedt.2017.06.002

Heckman, J. J., \& Kautz, T. (2012). Hard evidence on soft skills. National Bureau of Economic Research, Working Paper 18121. http://www.nber.org/papers/w18121 Retrieved on 13/5/2020. 
Henderson, N. (2013). Havens of resilience. Educational Leadership, 71(1), 22-27. https://www.sanpedrohs.org/ourpages/auto/2017/8/6/42260880/Havens_of_Resilience . pdf

Herrington, J., Reeves, T. C., \& Oliver, R. (2014). Authentic learning environments. In J. M. Spector, M.D. Merrill, J. Elen \& M.J. Bishop (Eds) Handbook of research on educational communications and technology (4 ${ }^{\text {th }}$ Edition) (pp. 401-412). New York, NY: Springer. Retrieved from: https://link.springer.com/chapter/10.1007/978-1-4614$\underline{3185-5 \_32}$

Johnson, L., \& Morris, P. (2010). Towards a framework for critical citizenship education. The Curriculum Journal, 21(1), 77-96. https://doi.org/10.1080/09585170903560444

Jones, T. S. (2004). Conflict resolution education: The field, the findings, and the future. Conflict Resolution 233-267. http://creducation.net/resources/resolving_conflicts/files/Jones\%20article.pdf

Joyce, B., Weil, M., \& Calhoun, E. (2015). Models of Teaching ( $9^{\text {th }}$ Edition). New York: Pearson.

Katsarou, E. \& Sipitanos, K. (2019). Contemporary school knowledge democracy: possible meanings, promising perspectives and necessary prerequisites. Educational Action Research 27 (1): 108-124. https://doi.org/10.1080/09650792.2018.1564688

Kolb, D. A. (2015). Experiential Learning: Experience as the source of learning and development ( $2^{\text {nd }}$ Edition). New Jersey: Pearson Education, Inc.

Landrum, T. J., \& Mcduffie, K. A. (2010). Learning styles in the age of differentiated instruction. Exceptionality, 18(1), 6-17. https://doi.org/10.1080/09362830903462441

Meiklejohn, J., Phillips, C., Freedman, M. L., Griffin, M. L., Biegel, G., Roach, A., ... \& Isberg, R. (2012). Integrating mindfulness training into K-12 education: Fostering the resilience of teachers and students. Mindfulness, 3(4), 291-307. https://doi.org/10.1007/s12671-012-0094-5

McLaren, P. (2003). Critical Pedagogy: A look at the major concepts. In A. Darder, M. Baltodano \& R. D. Torres (Eds), The Critical Pedagogy Reader (pp. 69-96). New York: Routledge Falmer.

McGuirk, P. M. \& O'Neill, P. (2016). Using questionnaires in qualitative human geography. In I. Hay (Eds.), Qualitative Research Methods in Human Geography (pp. 246-273). Don Mills, Canada: Oxford University Press. Retrieved from: https://ro.uow.edu.au/sspapers/2518/

Nair, P. (2014). Blueprint for tomorrow: Redesigning schools for student-centered learning. Cambridge, MA: Harvard Education Press.

Oser, F., \& Veugelers, W. (Eds.). (2008). Getting Involved. Global Citizenship Development and Sources of Moral Values. Rotterdam/Taipeh: Sense Publishers.

Patry, J.-L. (2012). Values and Knowledge Education (VaKE): Experiences with a means to achieve the Double Assignment (2012). Key note paper in the EARLI SIG 13 Symposium, June 18th-21st 2012. Bergen, NLA University College.

Petrik, A. (2013). Learning "How Society Is and Might and Should Be Arranged": Necessity and Outcome of Interactive and Controversial Teaching Strategies. In M. Print \& D. Lange (Eds.), Civic Education and Competences for Engaging Citizens in Democracies (pp. 79-98). Rotterdam: Sense Publishers.

Pnevmatikos, D., \& Christodoulou, P. (2018). Promoting conceptual change through Values and Knowledge Education (VaKE). In A. Weinberger, H. Biedermann, J.-L. Patry, S. Weyringer, (Eds.), Professionals' Ethos and Education for Responsibility, pp. 62-74. Leiden: Brill Sense.

Print, M., \& Lange, D. (2012). Schools, Curriculum and Civic Education for Building Democratic Citizens. Rotterdam: Sense Publishers. 
Rao, D., \& Stupans, I. (2012). Exploring the potential of role play in higher education: development of a typology and teacher guidelines. Innovations in Education and Teaching International, 49(4), 427-436. https://doi.org/10.1080/14703297.2012.728879

Şahin, F. S., Serin, N. B., \& Serin, O. (2011). Effect of conflict resolution and peer mediation training on empathy skills. Procedia-Social and Behavioral Sciences, 15, 2324-2328. https://doi.org/10.1016/j.sbspro.2011.04.101

Seira, E. \& Dimitriadou, C. (2017). Aspects of citizenship education in teaching ancient Greek historiography: A case study in $\alpha$ senior high school. Proceedings of the Third International Conference "Education across Borders. Education and Research across Time and Space" (pp. 850-859). Bitola, 6-7 October 2016.

Smith, P. K. (2004). Violence in schools: A European perspective, report for Organisation for Economic Co-operation and Development School Safety and Security. Paris: OECD. Retrieved from: http://www.oecd.org/edu/innovation-education/34739292.pdf

Tepovich, A., (2012). Fostering Resilience in At Risk High School Students (Master's Thesis). Retrieved from: http://files.eric.ed.gov/fulltext/ED530357.pdf

Turk, F. (2018). Evaluation of the effects of conflict resolution, peace education and peer mediation: A meta-analysis study. International Education Studies, 11(1), 25-43. Retrieved from: https://eric.ed.gov/?id=EJ1165110

Veugelers, W., \& de Groot, I. (2019). Theory and Practice of Citizenship education. In W. Veugelers (Ed.), Education for Democratic Intercultural Citizenship (pp. 14-41). Leiden: Brill Sense.

Veugelers, W., de Groot, I., \& Stolk, V. (2017). Research for CULT Committee - Teaching Common Values in Europe, European Parliament, Policy Department for Structural and Cohesion Policies, Brussels. http://dx.doi.org/10.2861/339926

Vrantsi, A., \& Dimitriadou, C. (2015). Tracing the consequences of financial crisis on primary school students: the case of Western Macedonia. Conference presentation in the $9^{\text {th }}$ Greek Conference of Hellenic Educational Society: "Greek Pedagogical and Educational Research". Florina, 28-30 November 2014 (in Greek).

Weinberger, A., Patry, J. L., \& Weyringer, S. (2017, June). Autonomy-supportive learning with VaKE (Values and Knowledge Education) in teacher education. Fostering empathy and cognitive complexity. In Proceedings of the 3rd International Conference on Higher Education Advances (pp. 109-116).

Williams, A., O'Driscoll, K., \& Moore, C. (2014). The influence of empathic concern on prosocial behavior in children. Frontiers in Psychology, 5(425), 1-8.

Woodhead, M. (2004). 'Psychosocial Impacts of Child Work: A Framework for Research, Monitoring and Intervention', International Journal of Children's Rights 12: 321-77. Retrieved from: https://core.ac.uk/download/pdf/82904287.pdf 